\title{
Economic Aspects of the Cold War, 1962-1975
}

\section{Citation}

Cooper, Richard N. 2008. Economic aspects of the Cold War, 1962-1975. WCFIA Working Paper 2008-0018.

\section{Published Version}

http://www.wcfia.harvard.edu/node/2590

\section{Permanent link}

http://nrs.harvard.edu/urn-3:HUL.InstRepos:3677060

\section{Terms of Use}

This article was downloaded from Harvard University's DASH repository, and is made available under the terms and conditions applicable to Other Posted Material, as set forth at http:// nrs.harvard.edu/urn-3:HUL.InstRepos:dash.current.terms-of-use\#LAA

\section{Share Your Story}

The Harvard community has made this article openly available.

Please share how this access benefits you. Submit a story.

\section{Accessibility}


February 2008

\title{
Economic Aspects of the Cold War, 1962-1975
}

\author{
Richard N. Cooper \\ Harvard University
}

US objectives during the Cold War were to prevent Soviet attacks on the United States and its allies and to prevent the spread of communism as a political and economic system to other countries, whether by force or by threat, subversion, persuasion, or bribery. The principal instrument to prevent attack was an extensive build-up of defensive and retaliatory military forces, combined with political and military alliances that extended US protection to other countries in exchange for their engagement and support. The principal instruments for preventing the spread of communism by non-military means involved building an international economic system conducive to economic prosperity; engaging in persuasion, providing incentives, and occasionally imposing economic sanctions; and, not least, promoting a robust US economy that could serve as a stimulant to others and as a beacon for the benefits of a free, enterprise-based, market-oriented economy.

This chapter will focus on the second set of instruments, usually neglected by historians of the Cold War in favor of focus on the actual or threatened military actions and the diplomacy associated with them. Following some introductory remarks, the chapter will discuss developments in the world economy and comparative economic performance between communist countries and what was called the "free world" over the whole period, followed by discussion of actions taken within the United States that were motivated, at least in part, by their international implications; and US public expenditures on national security and international affairs. A third section then considers US economic policy toward the communist countries, followed by sections on policies toward the allies (mainly western Europe and Japan) and toward the international economic system as a whole. The chapter concludes with a discussion of actions toward other non-communist countries, often loosely albeit unhelpfully called the Third World, where the competition was most visible. The main focus will be on the United States, which typically took the initiative, but other countries played important, sometimes critical, supporting roles. 
Economic policy, broadly interpreted, was an essential complement to the policy of deterrence. In the end, the Soviet Union was not defeated in military combat, but rather it collapsed because of internal economic weaknesses that were increasingly evident to the Soviet people and, more gradually, to their leaders. These emergent internal weaknesses marked a sharp contrast to the robust performance of economies in the orbit of the United States and its allies - first in western Europe and in Japan, followed soon by southern Europe and the four Asian tigers (South Korea, Taiwan, Hong Kong, and Singapore), with Thailand, Malaysia, Indonesia, and others starting down the same successful path. It was increasingly evident that communism did not work well economically - it did not deliver significantly higher standards of living to ordinary people - as became evident especially with the growing contrast between East and West Europe, between North and South Korea, and between the Peoples' Republic of China (China hereafter) and Taiwan and Hong Kong. After some initial successes, the communist countries became mired in inflexible systems of resource allocation and low levels of innovation in a world increasingly dominated by rapid technological advances. Not that all countries in the non-communist world did well. But many did, and after an initial spurt of capital-intensive industrialization economic performance deteriorated significantly in all communist countries. Gradually those countries in the non-communist world that experimented with central planning and control drew away from it - including eventually even China and Vietnam, which remained under political control by their communist parties.

It is necessary to recall the high promise which communism and central planning of the economy held out to many. Kim Philby, the Russian spy high in the British diplomatic corps, could still write from his Moscow exile as late as 1968 that he had no doubt that the verdict of history would be victory for communism. ${ }^{1}$ The battle of ideas was not decisive; but the cumulative experience was increasingly difficult to ignore. In the end, this cumulative comparative experience was at least as important in preventing the spread of communism as was deterrence. And of course economic prosperity in the West made it easier to carry the financial burdens of defense, deterrence, and containment.

All this would become evident with the passage of time. In the 1960s, however, communism was still seen as an aggressive, vigorous ideology, with continuing support from the Soviet Union but drawing also on indigenous revolutionary groups and idealistic new leaders around the world. Nearly every year

\footnotetext{
${ }^{1}$ Kim Philby, My Silent War, New York: Grove Press, 1968, p.90.
} 
brought forth some perceived new communist threat. Fidel Castro’s Cuba became increasingly communist from 1960. The Soviet Union sent funds and advisers to the leftist Prime Minister Lumumba of the Congo immediately following abrupt abandonment of its colony by Belgium, threatening the break-up of that newly independent country, and leading President Kennedy to take countervailing measures. The Soviet Union under Nikita Khrushchev tried once again to isolate Berlin in 1961, and a wall was built to prevent increasing migration of East Germans into more appealing West Berlin, thence into western Europe. The Soviet Union tried, with Cuban encouragement, to place missiles in Cuba in 1962, leading to the Cuban missile crisis. In 1962 China, still (erroneously) considered by many Americans to be a surrogate of the USSR, attacked Indian troops in areas claimed by India. In 1964 indigenous communist groups were disciplined enough to emerge successfully from anarchy in the Dominican Republic, prompting President Lyndon Johnson to send in US marines to re-establish order and an interim government. In 1965 communists in Indonesia staged a coup, possibly with the support of President Sukarno, threatening to take the world's fourth most populous country into the communist "orbit”; it was brutally suppressed by Indonesia's army. In 1967 Syria, with Soviet encouragement and support, promoted terrorist raids in Israel, leading ultimately to the Six Days War in June. In 1968 Soviet troops marched into Czechoslovakia, suppressing the "Prague Spring" and ushering in the Brezhnev Doctrine. In 1971 a left-wing president, S. Allende was contentiously elected in Chile. Even as late as 1975, communists made a serious run at taking over Portugal after the death of Salazar, its dictator for over 30 years, and immediately thereafter in Angola, newly liberated from Portugal.

And of course the conflict in Vietnam ran right through the entire period. So while the communists had few successes between 1960 (Cuba) and 1975 (Vietnam), they were vigorously pursuing opportunities around the world, always with encouragement and often with material support from the Soviet Union. President Richard Nixon could say to his senior officials in 1971 "the impressive thing about the Communist leaders is their total absolute conviction that they're going to win, and their determination to do everything to win.”2

These continuing episodes provide a backdrop for the efforts by leaders in the United States, Western Europe, Canada, and Japan to attempt to assure economic prosperity, both through national policy 
and through international cooperation. The main components of the strategy were already laid down in the late 1940s, with Marshall Plan aid to Europe, trade liberalization through the General Agreement on Tariffs and Trade (GATT), and President Harry Truman’s “Point Four,” calling for aid to developing countries. Private US investment abroad typically followed, although it was not a reliable instrument of policy. The International Monetary Fund and the World Bank, created in 1946, were also important features of the international economic architecture. The United States, with the sometimes reluctant cooperation of others, tried also to penalize countries within or too close to the Soviet orbit.

\section{World Economic Performance}

The 1960s was a decade of high global economic growth, perhaps the highest decadal growth in history. US growth was interrupted by recessions - declines in total production -- in 1960-61, 1970-71, and 1975. The rest of the world continued to grow during the first two US downturns, but global output declined following the nearly four-fold increase in world oil prices in 1974, resuming in 1976. Inflation increased in the major economies in the late 1960s, but remained modest compared with the acceleration of inflation associated with the two sharp oil price increases of 1974 and 1979-1980.

Continental western Europe and Japan, in particular, experienced extraordinary growth in the 1960s and early 1970s. This performance was no doubt influenced, in the case of Europe, by the formation of the European Economic Community in 1958 and the trade liberalization that ensued within Europe, as well as by the global trade liberalization brought about by successive GATT rounds of negotiation. In particular, imports of merchandise into the United States, the world's largest national economy, grew by 170 percent during the 1960 s, from $\$ 15$ billion in 1960 to $\$ 40$ billion in 1970 . Both the fact and the prospect of selling into the large US market stimulated growth-enhancing investment in Europe, Japan, and elsewhere.

The USSR and its Warsaw Pact allies were also growing rapidly during this period. There are serious measurement problems for any growing economy whose structure of production is changing rapidly, and those problems become acute for an economy, such as the Soviet Union, where resource allocation occurs on the basis of quantitative targets rather than through market-determined prices.

\footnotetext{
${ }^{2}$ H.R. Haldeman, The Haldeman Diaries: Inside the Nixon White House, NewYork: Putnam, 1994, entry
} 
Moreover, official Soviet growth figures are known to have an upward bias, due partly to some double counting, partly to the exclusion of the (slower growing) service sector. For all these reasons, considerable disagreement surrounds estimates of Soviet growth rates during this period. Thus official Soviet figures, which undoubtedly influenced the perceptions and the self-confidence of Soviet leaders, show growth of 10.1 percent a year during the 1950s, declining to a still high 7.0 percent during the 1960 s and to 5.3 percent during the 1970s. America’s Central Intelligence Agency, in contrast, basing its analysis on work by Abram Bergson and other American scholars, estimated Soviet growth rates at 6.0, 5.1, and 3.7 percent, respectively, during these three periods. ${ }^{3}$ On either measure, the USSR in the early 1960s was on a roll, reflected in Soviet Premier Nikita Khrushchev’s frequent exuberant boasts. Growth gradually declined on both measures, and the USSR had increasing difficulty in maintaining its economic growth, and particularly its growth of oil production, the major source of hard currency export earnings as well as a critical input into the Soviet economy and military machine. Inability to innovate, or even to absorb foreign innovations, loss of discipline among Soviet workers, and failure to maintain installed equipment and to scrap obsolete equipment have all been given as explanations for the gradual but steady decline in economic growth.

Foreign trade did not fit comfortably into national central planning. In 1949 the Soviet Union formed the Council for Mutual Economic Cooperation (Comecon) with its eastern European satellites, and over time developed a concept of the "socialist division of labor." But it was never received enthusiastically by many of Comecon's members, there was no effective mechanism for multilateral trade or for balancing trade over time, and trade was not thoroughly integrated into the five-year planning process. As a consequence, trade within Comecon was limited (compared for example, to that within western Europe), although the Soviet Union was the major source of oil for east European countries and Cuba. Trade with non-communist countries, sometimes occurring within the framework of barter agreements (e.g. with India), sometimes carried on in "hard" currency (mainly US dollars), was even more limited - partly because of the unfavorable treatment of Soviet exports, to be discussed further below,

\footnotetext{
for September 13, 1971.

${ }^{3}$ Paul R. Gregory and Robert C. Stuart, Russian and Soviet Economic Performance and Structure, $6^{\text {th }}$ edition, Reading, MA: Addison-Wesley, 1998, p.225.
} 
partly because of the cumbersome and awkward institutional arrangements for trade within the Soviet Union.

Trade with non-communist countries gradually increased during the 1960s and especially after Germany's Ostpolitik and the promulgation of detente in the 1970s. Exports by industrialized countries to the Comecon countries, partly on the basis of credits, grew from \$2.8 billion in 1960 to $\$ 8.7$ billion in 1970 to $\$ 34$ billion in 1975 to $\$ 58$ billion in 1980, before a cutback in the early 1980s following the Soviet invasion of Afghanistan. ${ }^{4}$ The share of market-oriented countries in total Comecon imports grew from 27 percent in 1960 to 34 percent in 1970 to 46 percent in 1975 . World trade grew modestly more rapidly than total Comecon trade, but trade within Comecon grew more slowly (see Chart 1). The main earner of hard currency for the Soviet Union was exports of oil, whose price rose gradually in the early 1970s and sharply in 1974, thus improving its export earnings and its terms of trade. Prices of oil exports to other Comecon countries were raised only gradually, thus implying a subsidy to those countries, but oil exports over allotment were priced at world prices and payable in dollars, a practice that did not please the Soviet Union's fraternal allies.

Table 1 provides estimates of annual average growth rates in GDP, by decade, for the USSR, eastern Europe, the USA, western Europe, and Japan. Several points are noteworthy. First, the USSR grew faster than the USA to 1970, raising Soviet GDP on one estimate from 35 percent of the US level in 1950 to 44 percent in 1975, before declining to 34 percent in $1990 .{ }^{5}$ Second, economic growth declined over time in all countries, but especially sharply in the Soviet Union and eastern Europe, less markedly in the United States. Third, these measures are for total output, not consumption or standards of living. In the Soviet Union 15-17 percent of GDP was devoted to equipping and supporting the military, and an even larger and growing portion was devoted to investment, which by all accounts was used very inefficiently. Thus the high growth in output was not always reflected in equally high growth in consumption. After the Hungarian revolt of 1956, in which workers conspicuously participated, Nikita Krushchev worried that the standard of life of ordinary Soviet citizens was not improving sufficiently, and therefore tried to cut down on military spending, and redirected resources into consumer goods, particularly food production. Without

\footnotetext{
${ }^{4}$ International Trade 1975-76, Geneva: General Agreement on Tariffs and Trade (GATT), table F.

${ }^{5}$ Calculated from Angus Maddison, The World Economy: A Millennial Perspective, Paris: Organization for Economic Development, 2001, pp.274-275.
} 
formally reversing this emphasis on agriculture, Leonid Brezhnev increased military spending in the mid1960s. However, Soviet standards of living increased respectably during the 1960s.

Fourth, a division of GDP by population yields output per capita, which showed Soviet "productivity" growing from 30 percent of the US level in 1950 to 38 percent in 1975, and declining to 30 percent by 1990. These figures are based on purchasing power parity calculations for the Soviet Union, which have always been problematic and contentious because of the absence of meaningful prices for Soviet-produced goods and services; it is now believed that they over-state the quality of Soviet goods and services, hence of Soviet GDP and output per capita.

Table 1: Annual Growth in Gross Domestic Product

\begin{tabular}{|l|l|l|l|l|l|}
\hline & USSR & East Europe & USA & West Europe & Japan \\
\hline & & (percent per & annum) & & \\
\hline $1950-1960$ & 5.2 & 5.1 & 3.5 & 4.9 & 8.8 \\
\hline $1960-1970$ & 4.8 & 4.3 & 4.2 & 4.8 & 10.5 \\
\hline $1970-1980$ & 2.4 & 3.8 & 3.2 & 3.0 & 4.5 \\
\hline $1980-1990$ & 1.5 & -0.2 & 3.2 & 2.2 & 4.0 \\
\hline
\end{tabular}

Source: calculated from Maddison (2001), pp. 275, 298, 329.

Finally, post-1991 work by Russian economists has judgmentally lowered growth rates during the Soviet period even below those estimated by the CIA, from which the growth rates reported in Table 1 have been adapted. ${ }^{6}$ But Soviet leaders in the 1960s and early 1970s may not have been aware of this weaker performance, since production in sectors in which they were especially interested, such as steel, cement, and oil were continuing to grow rapidly, and indeed by 1975 had overtaken that of the United States.

In any case, during the period covered by this chapter the Soviet economy was performing reasonably well, although market-oriented economies in Europe and Japan were growing even more rapidly, and in the case of Europe from a significantly higher base. Soviet leaders had reason to be confident in their economy - serious weaknesses showed up later -- but also to be concerned about the

\footnotetext{
${ }^{6}$ Gregory and Stuart, Russian Economic Performance, p.227.
} 
long-term prospects of communism as a method for organizing production compared with market capitalism.

\section{Economic and Other Policies within the United States}

President John F. Kennedy was convinced that US policy toward the USSR, and toward the world, must be based on a robust US economy. On the basis of its lack-luster performance in the late 1950s, he campaigned in 1960 that he would "get the economy moving again.” To that end, he proposed significant trade liberalization. To stimulate growth and domestic demand, he proposed an investment tax credit, and eventually a significant reduction in income taxes, which was finally legislated in 1964. As expected, economic growth improved, and indeed became too robust after the sharp build-up in military expenditures associated with Vietnam, such that President Lyndon Johnson (belatedly) proposed a tax increase in 1967, enacted in 1968. As the economy grew, so did government revenues.

A government's spending priorities can be found in its budget. Defense expenditures in the United States declined from a Korean War high of \$49 billion (13 percent of GDP) in 1953 to \$38 billion in 1955, and then rose gradually to $\$ 45$ billion (8.8 percent of GDP) in 1960 and to $\$ 49$ billion in 1965 (7.1 percent of a significantly larger GDP). The Vietnam war built them up to \$77 billion in 1968 (8.8 percent of GDP), whereupon they rose to $\$ 86$ billion (representing a sharp decline in real terms, because of inflation), 5.0 percent of GDP in 1976, and fell below five percent in the years 1977-1979.

During this period the United States also expanded its expenditures on "international affairs," mainly foreign assistance, but also including the Peace Corps and the US Information Agency. In addition, Federal government expenditures on higher education increased under the National Defense Education Act, as did the space program, both launched in 1958. Kennedy promised in 1961, following the manned earth orbit by Russian Yuri Gagarin, to land a man on the moon "before the decade is out" - an achievement accomplished in July 1969. Kennedy wanted to re-establish the United States as being on the frontiers of technology in the eyes both of Americans and around the world - not least in the Soviet Union. NASA's expenditures rose from nothing in 1958 to a peak of \$5.1 billion in 1965 before receding to below $\$ 3$ 
billion in 1974-1975. ${ }^{7}$ These government expenditures did not impose severe strains on the US economy except during the years of the rapid military buildup in Vietnam in the late 1960s..

\section{Trade and Financial Policy toward Communist Countries}

The use of economic sanctions was an on-going feature of US foreign economic policy. In the context of the Cold War, specific sanctions were used against North Korea, China, Cuba, and North Vietnam. But they were also used against the thoroughly anti-communist Trujillo regime of the Dominican Republic, against neutral India, and against NATO-member Portugal. The United States often resorted to sanctions when a foreign government's behavior displeased it. Other countries also used economic sanctions, although not so frequently as the United States, where members of Congress individually and collectively complain about foreign behavior, and want to employ economic sanctions against the offending foreign government.

Specific sanctions were threatened, introduced, or tightened against Cuba, the German Democratic Republic, the United Arab Republic (Egypt), North Vietnam, Chile, and Kampuchea (Cambodia); they were relaxed against Laos. But it needs to be emphasized that the United States threatened or imposed economic sanctions 26 times during the period 1960-1975, not counting US participation in UN sanctions against South Africa (1962), Portugal (1963), and Rhodesia (1965). ${ }^{8}$

Before addressing specific episodes, we need to describe US trade policy toward communist countries in the absence of specific sanctions. This consisted of three components: treatment of imports from communist countries; controls on exports to communist countries; and granting of official credits to foreign countries, e.g. by the Commodity Credit Corporation (CCC) for the purchase of US agricultural products or by the Export-Import Bank for the purchase of US equipment.

The basic tariff legislation of the United States was (and in 2008 remained) the infamous SmootHawley Tariff of 1930. These high tariffs had been greatly reduced through a series of reciprocal trade negotiations, bilateral in the 1930s, multilateral (under the auspices of GATT) thereafter. Tariff reductions to any country were typically extended to other countries under so-called most-favored-nation (mfn)

\footnotetext{
${ }^{7}$ US Bureau of the Census, Statistical Abstract of the United States 1991, Washington: Government Printing Office, p.597.
} 
treatment, both by US policy and as required by GATT for all signatories to GATT. The United States did not however extend mfn treatment to communist countries (except Yugoslavia and, after 1960, Poland). Thus while the Soviet Union, for example, could export to the United States, its goods had to pay the typically high 1930 tariffs, except for those goods on the duty-free list, mostly raw materials. A combination of central planning in the USSR, with tight control over foreign trade, and high import duties into the United States assured little trade between the United States and the USSR and other communist countries.

The United States also limited sales to the Soviet Union and its allies of military goods and of “strategic” goods that might have direct or indirect military application. This process started in 1948 and was formalized in the Export Control Act of 1949, which with amendments governed US exports thereafter. The United States also enlisted the cooperation of west European countries, and of Japan, in limiting such sales to the USSR and eastern European communist countries, and to communist China and North Korea - covering both strategic goods originating locally and reshipment of such goods from the United States. An initially secret Coordinating Committee (COCOM) was established to agree on lists of goods considered "strategic" and to discuss enforcement of the export controls.

Like other countries, the United States had mechanisms for extending official credits or credit guarantees to foreign purchasers of US exports, through CCC, Exim Bank, the Defense Department for credit on sales of military equipment, and the Agency for International Development (AID) or its predecessors for foreign economic assistance to poor countries. In general, communist countries were denied access to these credits, although occasional exceptions were made for CCC credits.

In addition to these three "penalties” for Soviet-affiliated communism (Yugoslavia was exempt after Tito’s break with Stalin in 1948), specific sanctions - effectively, a total embargo - had been applied to trade with North Korea after its invasion of South Korea in 1950, and to China after its entry into that war. Chinese and North Korean assets in the United States were also frozen, and all financial transactions between American residents and those countries required license. These embargoes continued through the 1960s; that against China was relaxed following President Nixon’s visit to China in 1972; that against North Korea continued into the $21^{\text {st }}$ century.

\footnotetext{
${ }^{8}$ Gary C. Hufbauer, Jeffrey Schott, and Kimberly Elliot, Economic Sanctions Reconsidered, revised,
} 
Trade with Cuba was partially embargoed, with increasing severity, starting in 1960, following nationalization of American-owned property, with inadequate promised compensation; the embargo continued into the $21^{\text {st }}$ century, over four decades later. In 1961 the German Democratic Republic, with the approval of the Soviet Union, put an economic squeeze on West Berlin, which was viewed increasingly as a disruptive island of growing prosperity surrounded by the GDR, and an unwanted source of attraction to East Germans, many of whom worked in the western sector. The United States and its allies protested vigorously and sent additional troops; economic sanctions against the GDR were seriously, and openly, considered. In the end the GDR backed off and instead built the infamous Berlin Wall between the east and west sectors of the city, closing West Berlin to East Germans, and the sanctions were not applied.

In 1963-65 the United States first threatened and then cut foreign aid and agricultural credits to the United Arab Republic (Egypt) following its intervention in Yemen (with possible threat to Saudi Arabia) and its support for rebels in Congo. In May 1964, following increasing infiltration and support for the Viet Cong in South Vietnam, the United States imposed an embargo on all economic transactions by Americans with North Vietnam, and froze North Vietnamese assets in the United States - an embargo that was terminated only in 1994. In 1975 President Gerald Ford imposed a total trade embargo on and froze the US assets of Kampuchea (Cambodia), following a self-designated "maoist" communist takeover of the country and moves to increase self-reliance and force many Cambodians into the countryside (and ultimately to their deaths).

The United States attempted to reward moves it considered positive as well as penalize countries that moved in the wrong direction. Thus in 1960 the United States extended mfn treatment to goods from communist Poland, as it had earlier done for Yugoslavia, as that country showed greater autonomy with respect to the USSR. Aid, turned off and on since 1956 as the communist Pathet Lao moved in and out of coalition governments and attempted to establish diplomatic relations with the USSR and China, was finally resumed to Laos in 1962, following the Geneva accord; and was suspended again in 1975 following a takeover by the Pathet Lao. Although rigidly authoritarian, Romania increasingly distanced itself from the USSR, following which the United States extended mfn treatment to imports from that country in 1975.

Washington: Institute for International Economics, 1990. 
This is not the occasion to evaluate the effectiveness of the sanctions, or the rewards. Suffice it to say that one detailed analysis found a mixed picture. Many of the sanctions were judged to have negligible effect on their stated objectives, such as the long-lasting embargo on Cuba, which arguably contributed to keeping Castro in power for more than four decades. But others, such as the cut-off of critical agricultural credits to Nasser's Egypt, arguably encouraged that country to pull back from its foreign interventions. ${ }^{9}$

By the mid 1960s the time seemed ripe to improve relations with the USSR - what later was called détente. Kennedy and Johnson started the process, banning atmospheric testing of nuclear weapons in 1963 and concluding the important non-proliferation agreement in 1968, to inhibit the spread of nuclear weapons. Johnson had hoped also to start negotiations on nuclear arms limits, anti-ballistic missiles and multiple independent re-entry vehicles (MIRVs), but an upcoming summit in Leningrad was cancelled following the Soviet invasion of Czechoslovakia. The process eventually led to the Anti-Ballistic Missile Treaty and an interim Strategic Arms Limitation agreement (SALT I) finally agreed at a Brezhnev-Nixon summit in May 1972.

Détente also involved increased East-West trade. As part of his bridge-building effort, Johnson tried to alter the discriminatory US trade policy in 1966, but failed to persuade the Congress. ${ }^{10}$ Germany's foreign minister (later Chancellor) Willie Brandt inaugurated Ostpolitik, with tacit US approval. In July 1972, after Nixon’s trip to China, the United States agreed to sell $\$ 750$ million of grain to the Soviet Union over the following three years (which was implicit acknowledgement that the Soviet economy could not by itself provide meat to its people on the scale desired). In October 1972 the two countries initialed a trade agreement that would extend mfn treatment to Soviet goods sold in the United States (which would have reduced US tariffs on average about 64 percent, from 24 percent to 8.6 percent), while the USSR agreed to a significant partial payment (of \$722 million) on its 1945 Lend Lease debts to the United States.

Some Americans were concerned about the inability of minorities, especially Jews, to emigrate from the USSR. The Soviets responded quietly by allowing more emigration, rising from 400 in 1968 to 35,000 in 1973. Senator Jackson (D-Washington) and Congressman Vanik (D-Ohio) added an amendment to the trade bill that was then passing through Congress to the effect that mfn could not be extended to non-

\footnotetext{
${ }^{9}$ Ibid.

${ }^{10}$ Lyndon Baines Johnson, The Vantage Point: Perspectives on the Presidency 1963-1969, New York: Holt, Rinehart, and Winston, 1971, pp.472-473.
} 
market (i.e., communist) countries that restrict emigration. Soviet officials suggested privately that emigration might reach 45,000, but bristled at any open US intervention in what they considered internal affairs. In the end, Nixon resigned over Watergate, the newly installed President Gerald Ford signed the Trade Act of 1974, including the Jackson-Vanik amendment (and a parallel piece of legislation that restricted - but did not prohibit - Export-Import Bank loans to the Soviet Union). The USSR backed out of the 1972 trade agreement, and Soviet goods never received mfn treatment.

The Jackson-Vanik amendment is an example of the ability of a determined Congress to thwart an American president's foreign policy. More generally, presidents must constantly ascertain whether they have at least the acquiescence of Congress in the actions they wish to pursue, and active support when additional funds are required.

The Yom Kipper war between Israel and Egypt of October 1973 led to an Arab oil embargo on the United States and a nearly four-fold increase in oil prices in 1974. This relieved the hard currency shortage of the oil-exporting Soviet Union and diminished its eagerness to receive mfn treatment from the United States.

Trade and Financial Policies toward Allies

The economic dimension of cold war policy was not confined to penalizing communist countries, or rewarding those who resisted the embrace of the Soviet Union. There was a more affirmative agenda. As often, its roots go back to the late 1940s. But the young president Kennedy became an articulate spokesman of the need for vigorous US leadership of an economically vital western world. He sounded the theme in his inaugural address in January 1961. His first year in office was plagued by the Bay of Pigs fiasco in Cuba and by the crises over Berlin and Congo.

A major element of the world economic system was the General Agreement on Tariffs and Trade (GATT), adopted by 23 countries in 1947, which both promulgated rules to guide states in their trading relationships and provided a forum for reducing tariffs and other restrictions on imports from their high levels of the late 1940s. By 1961 this liberalizing process seemed to have run out of steam. Moreover, six European countries had in 1958 created the European Economic Community (EEC), which when completed (in 1970) would become a trading entity larger than the United States, with a single negotiating 
authority. The United States desired the reluctant United Kingdom to join the EEC. With all this in mind, Kennedy proposed in January 1962 a bold new round of trade negotiations, in which (in contrast to earlier multilateral trade negotiations) tariffs would be cut across the board (with selective exceptions) by up to 50 percent - 100 percent for products for which the USA and the EEC together accounted for more than 80 percent of world exports, which was a respectable list if the UK joined the EEC, but not otherwise. It provided for elimination of duties on tropical products. And, domestically, it called for the first time for adjustment assistance for firms and workers who were hurt by the trade liberalization.

Kennedy identified five important changes in the world for proposing this legislation, one of which was the "communist aid and trade offensive" and the trebling of Soviet bloc trade with 41 noncommunist developing countries and the activity of Soviet trade missions around the world. The proposal was to be his top legislative priority in 1962, and created the basis for the subsequent Kennedy Round of trade negotiations. Kennedy identified seven benefits expected to flow from the legislation and subsequent trade liberalization. The first three concerned benefits to the US economy, including enhancing its capacity to bear burdens of defense, as well as that of its allies. The remaining four reasons - promoting the strength and unity of the West, proving the superiority of free choice, aiding developing nations, and maintaining US leadership of the free world - are suffused with references to competition with the "SinoSoviet world” and the importance of a liberal trading regime for winning that competition.

The results of the Kennedy Round, concluded in 1967, were less than hoped for, but nonetheless impressive. Britain did not join the EEC until 1973, delayed by a veto by President DeGaulle of France, so the provision for elimination of tariffs of manufacturing goods went unused. But tariffs were reduced by an average of about 35 percent on $\$ 40$ billion of world trade in the base year, 1964. Above all, it was a successful cooperative venture, overcoming parochial domestic interests, and bringing the "free world" closer together economically.

President Lyndon Johnson faced the domestic challenge of ensuring civil rights to American blacks and the domestic objective of introducing publicly-financed medical care for the aged and the poor furtherance of Franklin Roosevelt's New Deal, as he saw it. Apart from relations with the Soviet Union and the escalating conflict in Vietnam, Johnson faced the challenge - as did other Europeans - of dealing with Charles de Gaulle’s aspirations and ambitions for establishing France’s independence of the United 
States and its primacy in Europe. De Gaulle aggressively questioned the international role of the dollar in early 1965, and withdrew French forces from NATO’s integrated command (but did not withdraw from NATO) in March 1966. De Gaulle had earlier vetoed Britain’s application for EEC membership, and in July 1965 stymied the EEC by prohibiting his ministers from attending the decision-making Council of Ministers. De Gaulle desired France to have a relationship with the Soviet Union independent of, and different from, that of the United States and other European countries. The Soviets responded politely but warily. Their main concern was with Germany, and they flirted with various ideas for weaning Germany away from the western alliance. Johnson worked hard (and successfully) to keep Germany firmly with the West, even while making overtures to the Soviet Union on non-proliferation (which would effectively deny Germany nuclear weapons) and on strategic arms control.

Johnson unsuccessfully sought new tariff negotiating authority in May 1968. President Richard Nixon, breaking with the protectionist tradition in the Republican Party, and reflecting his view of America's proper role in the world, renewed the request in November 1969. New authority was finally granted by Congress in December 1974 (after Nixon had resigned), which provided the basis for US participation in the next major trade-liberalizing round of multilateral negotiations, the Tokyo Round, begun in 1973 and concluded in 1979.

The other main strand of post-1960 foreign economic policy with respect to Europe was mainly defensive. In 1944 forty-four nations had agreed in Bretton Woods, NH, to postwar rules governing financial transactions among countries, and on the creation of two new implementing institutions, the International Monetary Fund (IMF) and the International Bank for Reconstruction and Development (later known as the World Bank). The rules inter alia required restriction-free access to currency for current account transactions (e.g., trade and travel), nearly fixed exchange rates among currencies, and currency convertibility into gold for monetary authorities (but not for ordinary citizens), a commitment adopted only by the United States. As the Bretton Woods system came under increasing strain from the late 1950s, one strand of US policy was to avoid a collapse of this system. Various currencies, including the US dollar, came under pressure from time to time, and adjustments had to be made to deal with imbalances in international payments. The main thrust of US policy during the 1960s was to pursue actions that forestalled a serious financial crisis while still preserving high-priority US objectives, which included 
maintaining the Atlantic alliance, keeping British and US troops in Germany, maintaining and extending an open trading system, and pursuing the non-proliferation treaty and other initiatives. Cooperation of other countries was required, and the United States did not want to jeopardize that cooperation. Thus a series of temporizing measures were taken to head off periodic US payments crises. As President Johnson once said to a startled William McChesney Martin, chairman of the Federal Reserve Board, "I will not deflate the American economy, screw up foreign policy by gutting aid or pulling troops out, or go protectionist just so we can continue to pay out gold to the French at $\$ 35$ an ounce.”11.

One mechanism for supporting countries in financial trouble, especially if the trouble was due to currency speculation on a change in the official exchange rate, was to provide short-term credit to the country's monetary authorities to permit them to ride out the speculation until it reversed. Thus a mechanism was put in place to provide such credits, partly by the US Treasury's Exchange Stabilization Fund, partly through "swap” lines extended by the Federal Reserve System to other central banks. Through these mechanisms the United States provided short-term credits to Canada (1962, 1968), Italy (1963-64, 1975), Britain (many times), and France $(1968,1969)$. If the short-term credits could not be repaid quickly from reversals of speculative capital flows, they could be repaid by drawing on the IMF, another cooperative arrangement, for longer term credit.

Britain's budget and balance of payments were so heavily burdened that Prime Minister Harold Wilson considered not only pulling British troops east of Suez back into Britain, which was ultimately done, but also cutting significantly the British Army on the Rhine. Doing so would have increased pressure in the United States also to reduce its forces in Germany and elsewhere in NATO, actions that were already being pressed hard in the US Senate by Senator Mike Mansfield (D-Montana), during a period of intense fighting in South Vietnam. In addition to short-term financial support to Britain, the United States, itself facing financial pressure, launched in 1967 a tripartite burden-sharing discussion with Britain and Germany, during which financial arrangements were worked out (mainly through assured German purchases in Britain and, secondarily, in the United States) to ease the pressure in both countries to reduce troop levels in Germany.

\footnotetext{
${ }^{11}$ As paraphrased by Francis M. Bator, "Lyndon Johnson and Foreign Policy: the Case of Western Europe and the Soviet Union,” in Aaron Lobel, ed., Presidential Judgment: Foreign Policy Making in the White House, Hollis, NH: Hollis Publishing, 2001, p.175.
} 
The leading Western countries, joined by all members of the IMF, also agreed on a major reform of the international monetary system by creating a new, international money (for monetary authorities), the SDR, or as the financial journalists dubbed it, "paper gold," since it was to replace gradually the international monetary role of gold and ease the demand for dollars by central banks. The SDR was seen at the time as a major step forward toward international monetary cooperation, although it subsequently failed to live up to expectations.

Britain's balance of payments problems were eased following a 14 percent devaluation of the pound in November 1967. US balance of payments problems came to a head in August 1971, when President Nixon ceased convertibility of the US dollar into gold (for foreign monetary authorities), imposed a wage/price freeze in the United States to stop the momentum of inflationary pressures that had built up in the preceding four years, and imposed a ten percent surcharge on all dutiable imports into the United States - the last mainly to force other countries to negotiate seriously on a realignment of exchange rates. These tense negotiations were concluded in December 1971 with the Smithsonian agreement, which realigned exchange rates of the leading currencies against the dollar and provided for an increase in the official dollar price of gold. However, pressures continued in foreign exchange markets, and in March 1973 major currencies were allowed to float against the US dollar (Canada and Britain had earlier switched to floating exchange rates). Continental Europeans struggled to maintain a higher degree of exchange rate stability among their currencies, leading to the European monetary system in 1979 and eventually to a common European currency in 1999.

Thus in the early 1970s two key features of the Bretton Woods system were abandoned: gold convertibility of the dollar and fixed exchange rates among major currencies (many other countries around the world maintained fixed exchange rates with respect to the dollar, the French franc, the British pound, or some other currency). This traumatic period of financial turmoil prompted serious discussions of reform of the international monetary system, which in some respects had not matured even in the early $21^{\text {st }}$ century, but those issues lie outside a discussion of the Cold War, except insofar as they affected western cohesion and prosperity. Despite occasional monetary turmoil, the western economies generally performed well, as noted above. 


\section{Economic Policies toward Developing Countries}

The United States pursued an active policy toward the third world, or "developing countries," as they were designated in UN jargon - as did Canada and west European countries, joined by Japan as it became richer. Soviet interventions in developing countries, especially in the Middle East and Africa, mainly in the form of grants of military equipment and training and resident technical advisers, more rarely as financial assistance, were a source of frustration and irritation to successive American administrations during the 1960s and 1970s. The US government tried to counter these measures, both by pre-emption and by direct response.

The program that captured most imagination in the United States and indeed in many developing countries was the Peace Corps, created in 1961 by President Kennedy to mobilize the energy, enthusiasm, and idealism of young adults, as he thought the communist countries (especially Cuba) were able to do. This program sent volunteers (only expenses were covered by government) to developing countries to work in towns and villages on anything that could be helpful, mainly teaching and public health. Starting from nothing, the program grew to over 10,000 volunteers by 1964 , in 46 countries. ${ }^{12}$ It reached a peak expenditure of $\$ 110$ million in 1968, before declining as Nixon showed less interest in it. The volunteers were abroad neither as diplomats nor intelligence agents, but to do good in ways developed largely by each individual; to expose young Americans to different and much less privileged parts of the world; and to expose people in developing countries to idealistic Americans, unencumbered by the exigent requirements of US government policy. By all accounts the program was highly successful, both in recipient countries (the demand for volunteers greatly exceeded the supply) and for many of the Americans, some of whose later careers were decisively shaped by their Peace Corps experience. Kennedy also altered the guidelines of the US Information Agency, which spread information about the United States around the world, from providing doctrinaire material on the merits of capitalism to providing a more realistic and pluralistic account of life in the United States; and USIA's budget was nearly doubled over the decade 1960-1970.

Kennedy also built on earlier legislation in creating a "Food for Peace” program, whereby American agricultural products were exported to developing countries not only in humanitarian emergencies (e.g. due to drought) but more generally to alleviate malnutrition on an on-going basis and 
(through use of the local-currency proceeds from sale of products) to contribute to development projects through the budget of the recipient country. This program grew sharply from \$350 million in 1960 to over \$1.6 billion in 1965 before stabilizing between \$1-2 billion annually. It had the advantage of appealing greatly to US farmers, who under US agricultural support programs were producing surpluses of several products that periodically became fiscally burdensome. It had the disadvantage, as was later discovered, of diverting the attention of recipient governments away from improving their indigenous agricultural production and productivity, and sometimes depressing the incomes of their farmers. But it was typically appreciated by recipient governments, and it created a source of US leverage insofar the threat of cutting food aid could occasionally be used to alter undesired behavior, as noted above in the case of Egypt and perhaps most dramatically in the case of India.

The United States had had foreign assistance programs since the late 1940s, most notably the Marshall Plan to help Europe recover from the Second World War (eastern European countries were invited to join, but at Soviet insistence declined to participate -- one of the earliest signs of the sharp division of Europe that was to persist for four decades). After the Marshall Plan US bilateral aid (as opposed to loans for development projects from the World Bank) was largely in the form of technical assistance, until the Development Loan Fund was created by the Eisenhower administration in 1958. Kennedy felt that the US aid program lacked overall strategic vision, and that it was guided too much by short-term, Cold War considerations. Earlier programs were combined in 1961 into the Agency for International Development (AID), with the charge of focusing on economic development and taking a longer-term view of each recipient country's prospects and how they could best be assisted. Kennedy tried but failed to get Congressional support for multi-year appropriations, and his Department of Defense objected to incorporating military assistance in AID’s mandate. Moreover, economic assistance levels actually declined for several years due to Congressional skepticism combined with outright opposition. Nonetheless, US economic assistance was somewhat re-oriented toward development objectives. The largest recipients of US economic assistance during the period 1966-1972 were, in order of amount received, India, South Vietnam, Pakistan, South Korea, Israel, Brazil, Turkey, and Colombia, ranging from \$3.7 billion for India to $\$ 600$ million for Colombia.

${ }^{12}$ Arthur M. Schlesinger, Jr., A Thousand Days: John F. Kennedy in the White House, Boston: Houghton 
A component of economic assistance that received special attention was the Alliance for Progress. Latin America, it was felt, had been neglected by US policy-makers, and such attention as they did focus on the region went mainly to protecting American business interests. After the unhappy developments in Cuba, Kennedy felt the need for a more affirmative, pre-emptive program for Latin America, and the Alliance for Progress was his response. This component of the aid budget grew sharply over the decade of the 1960s - possibly with some effect, since Soviet adventurism there became notably lower than in some other parts of the world, although it was not altogether absent, and Cuba served as an instrument for encouraging and assisting revolutionary groups and local communist parties.

Finally, just as the Soviet Union supported many governments by providing arms and other military equipment, so did the United States. Indeed, the United States in total exported nearly twice the value of military equipment - some sales to allies, some provided as foreign assistance to developing countries. Both equipment and training were supplied. Military grants generally exceeded $\$ 1.5$ billion a year in the early 1960s, then rose steadily to a peak of $\$ 4.5$ billion in 1972 as the United States attempted to shift the military responsibility to the government of South Vietnam for defending the South against communist North Vietnam and its Viet Cong allies. Thereafter it receded to under \$3 billion (less in dollars of 1960, due to the inflation that occurred 1967-1975). The main recipients of military assistance in the early 1970s, apart from Vietnam, were Turkey and Greece in NATO, Israel, South Korea, Cambodia, Laos, Republic of China (Taiwan), Thailand, and Jordan, in that order, but many other countries received smaller amounts on a regular basis. ${ }^{13}$

One further channel of economic assistance needs to be mentioned: discriminatory trading arrangements. The newly established EEC, with its common external tariff, provided preferential access to the European market (e.g. through lower tariffs, or higher quotas on selected agricultural products) for former European colonies in the so-called ACP (for Africa, Caribbean, Pacific) regions, i.e. excluding larger former colonies such as India, Pakistan, Indonesia, and Vietnam. Thus goods from selected small countries got preferential access to the European market. In the mid-1960s the developing countries, through the newly created UN Conference on Trade and Development (UNCTAD), called for extending tariff preferences by all rich countries to all poor countries. The Generalized System of Preferences (GSP),

Mifflin, 1965, p.607. 
as it was called, was first embraced by Australia, Europe, and Canada , and only later by a more reluctant Japan and United States. President Johnson accepted GSP for the United States only in 1967, but it required legislation, so was not legally adopted until the Trade Act of 1974, and could not be implemented until 1976. Neither the European nor the US scheme, which differed in important detail, was nearly as generous as advocates had in mind; but they arguably encouraged some private investment in developing countries to take advantage of the tariff preferences.

The Soviet Union also purchased products from its client states, most notably sugar from Cuba, which could not be sold to the United States because of its embargo, or to Europe because of its agricultural protection. But Soviet trade was all undertaken by a monopoly trading ministry, so sales were subject to government-to-government negotiation, and had to fit into the requirements of the five-year economic plan or else was regarded as outright aid.

The real "battleground” of the Cold War after the early 1960s was thus competition for influence in developing countries, through trade, financial and technical aid, military assistance in the form of equipment and training. Both the USSR and the USA also had programs for bringing students to their respective universities. Soviet ambassador to the United States Anatoly Dobrynin could lament, in his memoirs published many years later, that "détente was to a certain extent buried in the fields of SovietAmerican rivalry in the Third World."14

\section{$\underline{\text { Summary }}$}

From the perspective of Soviet leaders, the Soviet Union in the mid-1970s was doing very well in its economic competition with the United States. Its aggregate productioin had risen slowly but steadily relative to US production, and output of products of special interest, such as steel, had come to exceed US production. The major hard currency exports of the Soviet Union, crude oil and gold, had enjoyed substantial increases in price on the world market. At the same time, the "capitalist” world economy was in turmoil, experiencing in 1975 its worst recession since the 1930s. The Bretton Woods system of financial cooperation was in disarray, and the onset of "stagflation” created serious dilemmas of policy in most

\footnotetext{
13 Statistical Abstract 1978, Table 1508.

14 Anatoly Dobrynin, In Confidence: Moscow’s Ambassador to America’s Six Cold War Presidents, 19621986, New York: Times Books, 1995, p.473.
} 
market-oriented economies. In short, communists could confidently expect the ultimate victory of communism against the ailing capitalist system.

This self-satisfaction neglected the fundamental recuperative capacities of market capitalism. Incentives for adaptation, innovation, and private initiative remained strong. To take only one example, the integrated circuit, introduced in the early 1970s, was to revolutionize computation, communication, and much else, including military applications. While the communist system could dictate heavy investment in traditional products, it did so inefficiently and inflexibly, without extensive innovation. It could not adapte well to changes in technology and to changes in the composition of demand. By the mid-1980s, Soviet President Mikael Gorbachev would declare, "We cannot go on like this," and inaugurated his ultimately unsuccessful economic reforms of the Soviet system of communism. 